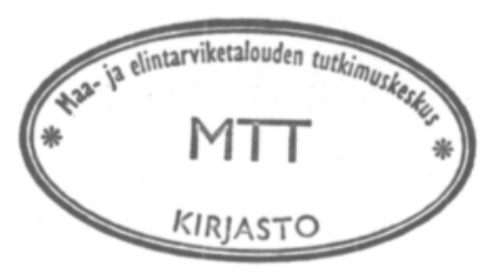

\title{
CERTAIN PARASITES OF FUNGAL SCLEROTIA
}

\author{
LEILA-RIITTA ERVIÖ \\ Department of Plant Pathology, University of Helsinki
}

Cultures have been made on a total of 51 different microbe isolates which have proved to be antagonistic to certain pathogenic fungi of cultivated plants. Among these isolates were some fungal species parasitizing the sclerotia of Sclerotinia trifoliorum Erikss., S. borealis Bub. \& Vleugel, S. sclerotiorum (Lib.) Bref., Claviceps purpurea TUL. and Botrytis cinerea PERS., as well as some bacteria having an antibiotic effect on S. trifoliorum $(5,6,8,9,10,11,12)$.

\section{Materials and methods}

The sclerotia of S. trifoliorum and S. sclerotiorum were cultivated in the laboratory at a temperature of about $10^{\circ} \mathrm{C}$ on Henneberg agar $\left(10 \mathrm{~g}\right.$ peptone, $2 \mathrm{~g} \mathrm{NH}_{4} \mathrm{H}_{2} \mathrm{PO}_{4}$, $2 \mathrm{~g} \mathrm{KNO}_{3}, 0.5 \mathrm{~g} \mathrm{MgSO}_{4}, 0.1 \mathrm{~g} \mathrm{CaCl}_{2}, 100 \mathrm{~g}$ glucose, $20 \mathrm{~g}$ agar, $1000 \mathrm{ml}$ distilled water). The sclerotia of Botrytis cinerea grew best when cultivated at $15^{\circ} \mathrm{C}$ on low-sugar Czapek's agar $\left(3.0 \mathrm{~g} \mathrm{NaNO}_{3}, 1.0 \mathrm{~g} \mathrm{~K}_{2} \mathrm{HPO}_{4}, 0.5 \mathrm{~g} \mathrm{MgSO}_{4} \cdot 7 \mathrm{H}_{2} \mathrm{O}, 0.5 \mathrm{~g} \mathrm{KCl}\right.$, $0.01 \mathrm{~g} \mathrm{FeSO}_{4} \cdot 7 \mathrm{H}_{2} \mathrm{O}, 30 \mathrm{~g}$ sucrose, $15 \mathrm{~g}$ agar, $1000 \mathrm{ml}$ distilled water).

The sclerotia of S. trifoliorum and S. sclerotiorum were transferred outdoors in November 1961 and 1962. They were placed on the surface of soil in wooden boxes $(15 \times 25 \mathrm{~cm})$ which had been buried in the ground and filled with earth. Every month during the winter and spring, up to the month of May, one box was brought inside and the sclerotia examined. In general, no fungal mycelium nor bacterial slime, was seen on the sclerotia. By scraping their surface with an inoculation needle a sample was taken to be cultivated on Czapek's agar medium in Petri dishes. The microorganisms which grew from these samples were isolated, and their parasitic or antibiotic effect on S. trifoliorum was studied. Most of the fungi which appeared were the same as those which had previously been included in the collections of the 
Department of Plant Pathology; they were not further cultivated, with the exception of one isolate of Acrostalagmus roseus. Likewise, no cultures were made of the microbe isolates which had no antagonistic influence on the pathogenic fungi under study. As a rule, the bacteria which were isolated from the sclerotia had no significance as parasitic agents. Microbes were also isolated from the remains of dead clover plants on the field at different times of the year, as well as from the surface of sclerotia in laboratory trials, where they appeared as contaminants.

The isolated fungi were used to infect the sclerotia of S. trifoliorum, S. sclerotiorum and Botrytis cinerea. An isolate of $A$. roseus, which proved to have an exceptionally potent infective ability, was used as control $(3,6)$. The sclerotia were infected by immersing them for about two hours in a suspension of conidia and mycelial fragments of the parasite in distilled, autoclaved water. The sclerotia were then transferred to a moist, sterilized quartz sand medium in Petri dishes, which were kept at room temperature. The infective ability of two of the isolates, was studied at three different temperatures. In this case, the substrates were sterilized quartz sand and unsterilized soil.

\section{Isolated microbes and their ability to infect sclerotia}

In the years 1962 - 63 the following fungi found to have an antagonistic effect on phytopathogenic fungi were isolated.

Rhizopus nigricans EHRENB. (4, 14). Isolated from dead clover under the snow, 26. 3. 1962. The infection trials revealed that this isolate was a parasite of the sclerotia, infecting a greater number of sclerotia than $A$. roseus I (Table 1). However, only a small part of the infected sclerotia were destroyed during the 6-week trial period. The isolate grew rapidly and when cultivated on Henneberg agar it covered the entire surface of the Petri dish in two days. Colonies were formed by stolons, from which in certain spots branched hyphae attached themselves to the substrate by means of rhizoids. Sporangiophores arose from the mycelia in clusters. The sporangia and columellae were globose, the former having an average diameter of

Table 1. The ability of parasitic fungi to infect sclerotia on sterilized quartz sand substrate at room temperature. The number of sclerotia of each species varied from 10 to 30 . Trial period 6 weeks.

\begin{tabular}{|c|c|c|c|c|c|c|}
\hline \multirow[t]{2}{*}{ Isolate } & \multicolumn{3}{|c|}{$\%$ of sclerotia infected } & \multicolumn{3}{|c|}{$\begin{array}{l}\% \text { of infected sclerotia } \\
\text { destroyed during trial } \\
\text { period }\end{array}$} \\
\hline & $\begin{array}{l}\text { S. trifo- } \\
\text { liorum }\end{array}$ & $\begin{array}{l}\text { S. scle- } \\
\text { rotiorum }\end{array}$ & $\begin{array}{l}\text { B. cine- } \\
\text { rea }\end{array}$ & $\begin{array}{l}\text { S. trifo- } \\
\text { liorum }\end{array}$ & $\begin{array}{l}\text { S. scle- } B \\
\text { rotiorum }\end{array}$ & $\begin{array}{l}\text { cine- } \\
\text { rea }\end{array}$ \\
\hline A. roseus $\mathrm{I}$, control & 36.7 & 100 & 100 & 13.3 & 90 & 100 \\
\hline A. roseus II & 90 & - & 95 & 90 & - & 95 \\
\hline Rhizopus nigricans & 60 & 100 & 100 & 10 & 30 & 100 \\
\hline Sporotrichum carnis & 30 & 20 & 100 & 0 & 20 & 100 \\
\hline
\end{tabular}


Table 2. The ability of Coniothyrium minitans isolate $\mathrm{I}$ to infect sclerotia on autoclaved quartz sand substrate at different temperatures. Trial period 6 weeks.

\begin{tabular}{|c|c|c|c|c|c|c|c|c|c|}
\hline \multirow{3}{*}{ Isolate } & \multicolumn{9}{|c|}{$\%$ of sclerotia infected (out of 30 ) } \\
\hline & \multicolumn{3}{|c|}{ S. trifoliorum } & \multicolumn{3}{|c|}{ S. sclerotigrum } & \multicolumn{3}{|c|}{ B. cinerea } \\
\hline & $20^{\circ} \mathrm{C}$ & $9^{\circ} \mathrm{C}$ & $3^{\circ} \mathrm{C}$ & $20^{\circ} \mathrm{C}$ & $9^{\circ} \mathrm{C}$ & $3^{\circ} \mathrm{C}$ & $20^{\circ} \mathrm{C}$ & $9^{\circ} \mathrm{C}$ & $3^{\circ} \mathrm{C}$ \\
\hline A. roseus $\mathrm{I}$, control & 36.7 & 10 & 6.7 & 20 & 10 & 0 & 100 & 100 & 0 \\
\hline C. minitans & 50 & 13.3 & 6.7 & 3.3 & 0 & 0 & 100 & 100 & 100 \\
\hline
\end{tabular}

Table 3. The infective ability of $C$. minitans on different substrates and at different temperatures.

Substrate and isolate

$\%$ of sclerotia infected (out of 40 )

\begin{tabular}{|c|c|c|c|c|c|c|c|}
\hline \multicolumn{2}{|c|}{ S. trifoliorum } & \multicolumn{3}{|c|}{ S. sclerotiorum } & \multicolumn{3}{|c|}{ B. cinerea } \\
\hline $20^{\circ} \mathrm{C} \quad 9^{\circ} \mathrm{C}$ & $3^{\circ} \mathrm{C}$ & $20^{\circ} \mathrm{C}$ & $9^{\circ} \mathrm{C}$ & $3^{\circ} \mathrm{C}$ & $20^{\circ} \mathrm{C}$ & $9^{\circ} \mathrm{C}$ & $3^{\circ} \mathrm{C}$ \\
\hline
\end{tabular}

Unsterilized soil:

C. minitans I

C. minitans II

$\begin{array}{rlr}17.5 & 0 & 0 \\ 7.5 & 2.5 & 10\end{array}$

$\begin{array}{lll}72.5 & 37.5 & 75\end{array}$

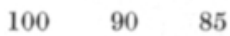

Sterilized quartz sand:

C. minitans I

$\begin{array}{lll}17.5 & 52.5 & 25\end{array}$

$92.5 \quad 55 \quad 5$

$\begin{array}{lll}90 & 95 \quad 100\end{array}$

C. minitans II

$\begin{array}{lll}47.5 & 70 & 42.5\end{array}$

$\begin{array}{lll}32.5 & 30 & 40\end{array}$

$100 \quad 100 \quad 100$

$\begin{array}{llllll}67.5 & 62.5 & 67.5 & 100 & 100 & 100\end{array}$

$225 \mu$ and the latter $75 \mu$. The sporangiophores were dark-coloured, irregularly shaped or globose and furrowed. Their size ranged from $5.2 \times 8.0 \mu$ to $9.5 \times 12.7 \mu$. A few oval zygospores, having a diameter of $160-220 \mu$, also appeared in the mycelia. There were no chlamydospores. $R$. nigricans, which is a common soil fungus, can sometimes injure also cultivated plants (14). In some studies this species has been observed under certain conditions to hinder the growth of Fusarium udum, Venturia inaequalis and Ophiobolus graminis $(13,15,19)$.

Sporotrichum carnis BROOKS \& HANSFORD (4). Syn. Aleurisma carnis (BROOKS \& HANSFORD) BISBY. Isolated on 15. 5. 1962 from a sclerotium of S. trifoliorum which had been outdoors the entire winter. The isolate had a somewhat weaker infective ability than $A$. roseus No. I. It was, however, definitely a parasite, since it completely destroyed the susceptible sclerotia of B. cinerea (Table 1). On Czapek's agar medium the colonies of this fungus were flat, initially whitish, later greyish. The hyphae were interwined and branched, $1-2 \mu$ in diameter. The conidiophores were short and branched, the conidia were oval and averaged $2.8-3.8 \mu$ in size (Fig. 1). VartiovaARA $(17,18)$ found that $S$. carnis has effectively decomposed cellulose. It has also been established to grow even at a temperature as low as $-6^{\circ}$ C (2).

Coniothyrium minitans CAMPB. (1). Two isolates of which isolate I was isolated on 24. 5. 1962 from seed of Lakeland red clover imported from the U.S.A. and isolate 


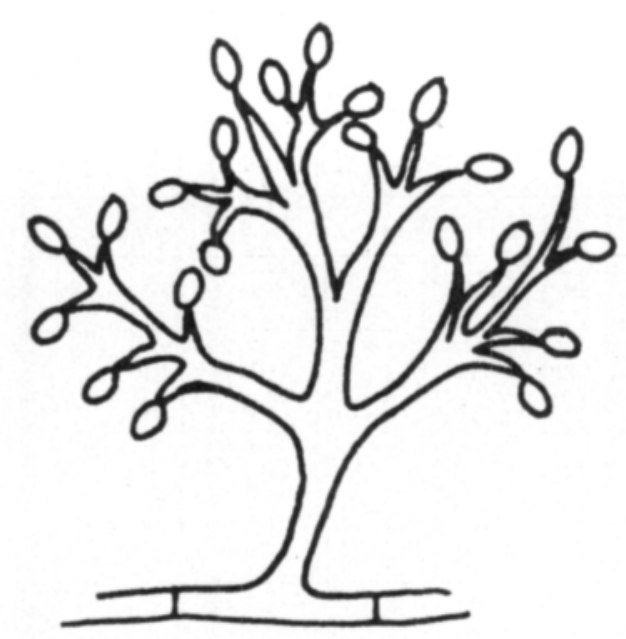

Fig. 1. Sporotrichum carnis. Conidiophore and conidia from a 10-day old culture on Czapek's agar medium. $\times 1000$.

II on 24. 11. 1962 from the surface of a sclerotium of $S$. trifolorum which had been outdoors. In preliminary trials $C$. minitans isolate I was nearly as potent a parasite as A. roseus I (Table 2). Its infective ability was greatest at room temperature.

The relative infective ability of the two isolates of $C$. minitans was determined on two different substrates in Petri dishes: unsterilized soil medium and sterilized quartz sand. On both kinds of substrate, sclerotia of S. trifoliorum, S. sclerotiorum and $B$. cinerea were infected. It was found that on the unsterilized soil medium both isolates caused about the same amount of infection (Table 3). On the other hand, when the substrate was autoclaved quartz sand, isolate II infected considerably more sclerotia than isolate I.

On Czapek's agar medium both isolates formed a mycelium which was white, somewhat curled and wooly (Fig. 2). About two weeks after inoculation, pycnidia began to form in the centre of the colony; these were at first covered by a thin, wooly mycelial layer. The pycnidia were black, globose, $190-600 \mu$ in diameter. The ostiole, from which the conidia were released in a black mass, was located in the centre of the upper surface of the pycnidium. The conidia were brown, globose or elliptical in shape, having either a smooth or rough surface and a size of $3.2-3.9 \times$ $3.9-4.8 \mu$. C. minitans is known as an effective parasite of Sclerotinia species (1, $16,20)$.

Acrostalagmus roseus BAINier $(3,4,6,12)$. A new strain was isolated on 7.6. 1963 from a sclerotium of $S$. trifoliorum in an infection trial, where it had appeared as a contaminant. It proved at least in preliminary trials to be an even more aggressive parasite than A.roseus isolate I, and therefore it was included in the collection of the Department of Plant Pathology for further studies. On Henneberg agar medium it had a slight antibiotic effect on $S$. trifoliorum. In preliminary trials $A$. roseus isolate II caused a more severe infection of sclerotia than the other antagonists studied (Table 1). Also in these trials, the sclerotia of $B$. cinerea were most readily attacked and destroyed. The most resistant sclerotia were those of S. trifoliorum, but even a considerable number of these were destroyed by A. roseus isolate II. 


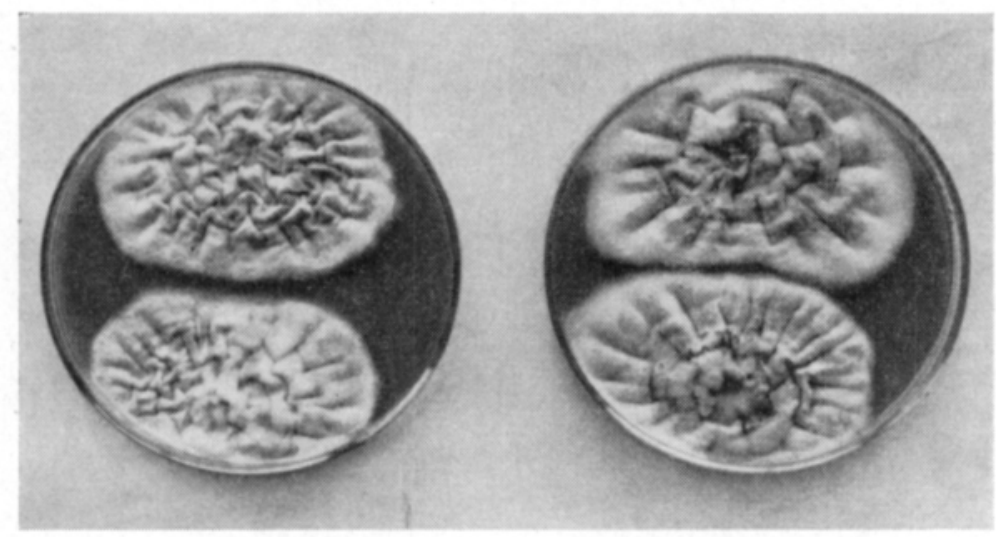

Fig. 2. Coniothyrium minitans. Isolates I and II on Henneberg agar medium.

When cultivated on Czapek's and on Henneberg agar media, the external appearance of this isolate differed from that of the previous isolate of A. roseus I in that its conidia were covered by only a very thin slime so that the mycelium as a whole appeared dry. The structure of the conidiophores and the conidia, however, were typically those of $A$. roseus $(4,12)$. The conidiophores were septate, verticillately branched, and had average dimensions of $3 \mu$ in diameter and 128-195 $\mu$ in length (Fig. 3). The conidia were oval or globose, $2.1-3.5 \times 3.5-4.5 \mu$ in size.

Fig. 3. Acrostalagmus roseus, isolate II. Conidiophore and conidia from a 14-day old culture on Henneberg agar medium. $\times 1000$.

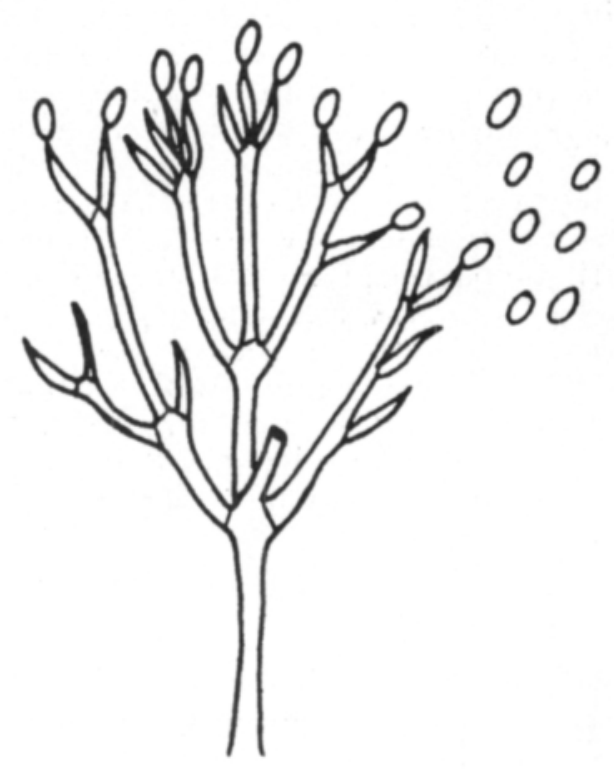

Conclusions

Rhizopus nigricans EHRENB., Sporotrichum carnis BROOKS \& HANSFORD, Coniothyrium minitans САMPB. (two isolates) and Acrostalagmus roseus BAINIER proved to infect sclerotia of Sclerotinia trifoliorum, S. sclerotiorum and Botrytis cinerea in laboratory experiments. The most effective of these was A. roseus. 
(1) Campbell, W. A. 1947. A new species of Coniothyrium parasitic on sclerotia. Mycologia 39: 190 -195 .

(2) Conner, J. W. 1947. Microorganisms and foods. Part II. Canad. Food Packer 43, 3: $19-21$.

(3) Erviö, Leila-Ritta, \& Halkilahti, Anna-Marja \& Pohjakallio, Onni 1964. The survival in the soil of sclerotia of two Sclerotinia species and their ability to form mycelia. Repr. from Advancing Frontiers of Plant Sci. 8: 121-134.

(4) Gilman, Joseph C. 1957. A Manual of Soil Fungi. 450 p. Iowa U.S.A.

(5) Karhuvana, Laura 1960. On the Parasites of the Sclerotia of some Fungi. Acta Agr. Scand. 10: $127-134$.

(6) Makkonen, Rauha \& Pohjakallio, Onni 1960. On the parasites attacking the sclerotia of some fungi pathogenic to higher plants and on the resistance of these sclerotia to their parasites. Ibid. 10: 105-126.

(8) Рohjakallio, OnNi 1960. Untersuchungen über Antagonisten der Erreger von Pflanzenkrankheiten. Verhandl. IV. Intern. Pflanzenschutz Kongresses Hamburg 1957 Bd. 2: 1541-1543. Braunschweig.

(9) - - \& SAlonen, Arvi 1950. On the appearance and significance of fungi and bacteria antibiotically affecting the fungus Sclerotinia trifoliorum ERIKss. Maataloustiet. Aikak. 22: $63-67$.

(10) - - SALONEN, ARvi \& LAAKKonen, EInI 1949. Investigations into the bacteria antibiotically affecting the fungus Sclerotinia trifoliorum Erikss. Physiologia Plantarum 2: 312-322.

(11) - - SAlONEN, ARvi \& RELANDER, Eeva 1953. Investigations into the micro-organisms limiting damage by the clover rot fungus. Acta Agr. Scand. 3: 53-60.

(12) - - SAlonen, Arvi, \& Ruokola, Anna-Lissa \& Ikäheimo, Katri 1956. On a mucous mold fungus, Acrostalagmus roseus BAINIER, as antagonist to some plant pathogens. Ibid. 6: $178-194$.

(13) Slagg, C. M. \& Fellows H. 1947. Effects of certain soil fungi and their by-products on Ophiobolus graminis. J. Agric. Res. 75: 279-293.

(14) Sмгтн, G. 1960. An introduction to industrial mycology. 399 p. London.

(15) Thirty-second and thirty-third Reports of the Quebec Society for the Protection of Plants 1950 \& 1951. $232 \mathrm{p}$.

(16) TRIEBE, H. T. 1957. On the parasitism of Sclerotinia trifoliorum by Coniothyrium minitans. The British Myc. Soc. Transact. 40: 489-499.

(17) VartiovaAra, Unto 1935. Maaperän sienten aineenvaihduntaa koskevia tutkimuksia. Acta Agr. Fenn. 32: 1-113.

(18) - 1938. The associative growth of cellulosedecomposing fungi and nitrogenfixing bacteria. Maataloustiet. Aikak. 10: 241-264.

(19) Vasudeva, R. S. \& Govindaswamy, C. V. 1953. Studies on the effect of associated soil microflora on Fusarium udum BurL., the fungus causing wilt of Pigeon-Pea (Cajanus cajan (L.) Mrllsp.) with special reference to its patogenicity. Ann. appl. Biol. 40: 573-583.

(20) ZuB, J. 1960. Novy dla Polski gatunek Grzyba: Coniothyrium minitans CampB. nadpasozyt raka Koniczynowego (Sclerotinia trifoliorum ERIKss.). Biul. inst. Ochr. Ros'. Poznan, 1960, pp. $171-180$.

\title{
S E L O S T U S:
}

\section{SIENIEN SKLEROOTIOIDEN ERÄISTÄ LOISISTA}

\author{
Leila-Rittta Erviö \\ Helsingin yliopiston kasvipatologian laitos
}

Viljelykasvien patogeenien antagonisteja koskevissa tutkimuksissa v. 1962-63 todettiin, että sienet Rhizopus nigricans EHRENB., Sporotrichum carnis BROOKS \& HANSF., Coniothyrium minitans CAMBP. ja Acrostalagmus roseus BAINIER, isolaatti II, tuhosivat laboratoriokokeissa Sclerotinia trifoliorumin, S. sclerotiorumin ja Botrytis cinerean sklerootioita. Tehokkain näistä oli Acrostalagmus roseus. 